\title{
AS TRANSFORMAÇÕES NO CENARIO URBANO EM PORTO ALEGRE: UMA ETNOGRAFIA DA LEMBRANÇA
}

Olavo Ramalho Marques

Ana Luiza Carvalho da Rocha (Orientação).

\section{Introdução}

Este trabalho vem no intuito do estudo da memória coletiva e da estética urbana em Porto Alegre, sendo o centro de interesses as transformações na paisagem urbana e as consequiências destas na vida de seus habitantes. A cidade é vista enquanto cenário da vivência cotidiana de seus moradores, e, em função disto, busca-se nas memórias deles a forma de percepção e ocupação deste espaço.

Neste sentido é fundamental a tentativa de trazer a tona lembranças dos modos de ocupação e transformação do espaço vivido pelos porto-alegrenses, já que estes deslocamentos contam-nos, também, a história da cidade enquanto cenário. Os vínculos entre a memória e tais deslocamentos são estreitos e é a partir destes elementos que o trabalho que se segue joga com a tensão entre o velho e o novo. A cidade se apresenta como um construto incrivelmente dinâmico, sofrendo alterações e transformações constantes. Ela é resultado da obra de um enorme número de construtores, sendo destruída e reconstruída constantemente por aqueles que compartilham seu espaço. As grandes metrópoles, que aglomeram milhares de vidas, são palcos em ininterrupto movimento. "O que buscamos, em nosso caos urbano, não é uma ordem definitiva e sim algo aberto às possibilidades, capaz de um ininterrupto desenrolar" (Linch, 1974:14). Todos os dias há prédios sendo erguidos e outros indo ao chão; há um fluxo de veículos e pedestres em todas as direções; há máquinas trabalhando nas ruas diariamente. A cidade é, assim, o palco primordial da vida moderna. 
Dentro desta perspectiva, foi realizado um trabalho de campo acompanhando um trecho das obras de abertura da III Perimetral em Porto Alegre, situado na avenida Salvador França. A cidade de Porto Alegre, por medida preventiva a possíveis ataques inimigos espanhóis, lutando pela posse do território do sul do Brasil -, desenvolveu-se à beira do estuário do Guaíba, com o centro da cidade limitado pelas águas. Assim, o tráfego de veículos é algo problemático, e ruas que servem de anéis viários são construídas para um melhor fluxo do trânsito, desviando-o do centro. Trata-se de um processo de cirurgia urbana em curso; os antigos logradouros, as ruas estreitas que remetem a uma cidade antiga são destruídos e dão lugar a grandes artérias que facilitam e viabilizam o fluxo do grande volume de automóveis que temos hoje, nas grandes metrópoles. ${ }^{1}$ O processo de pesquisa de campo se deu buscando compreender a parte daqueles que trabalham na obra, dos agentes da transformação, através do recurso da imagem fotográfica, bem como o ponto de vista dos moradores do bairro Jardim Botânico, e a descaracterização do modo de organização do espaço deste bairro.

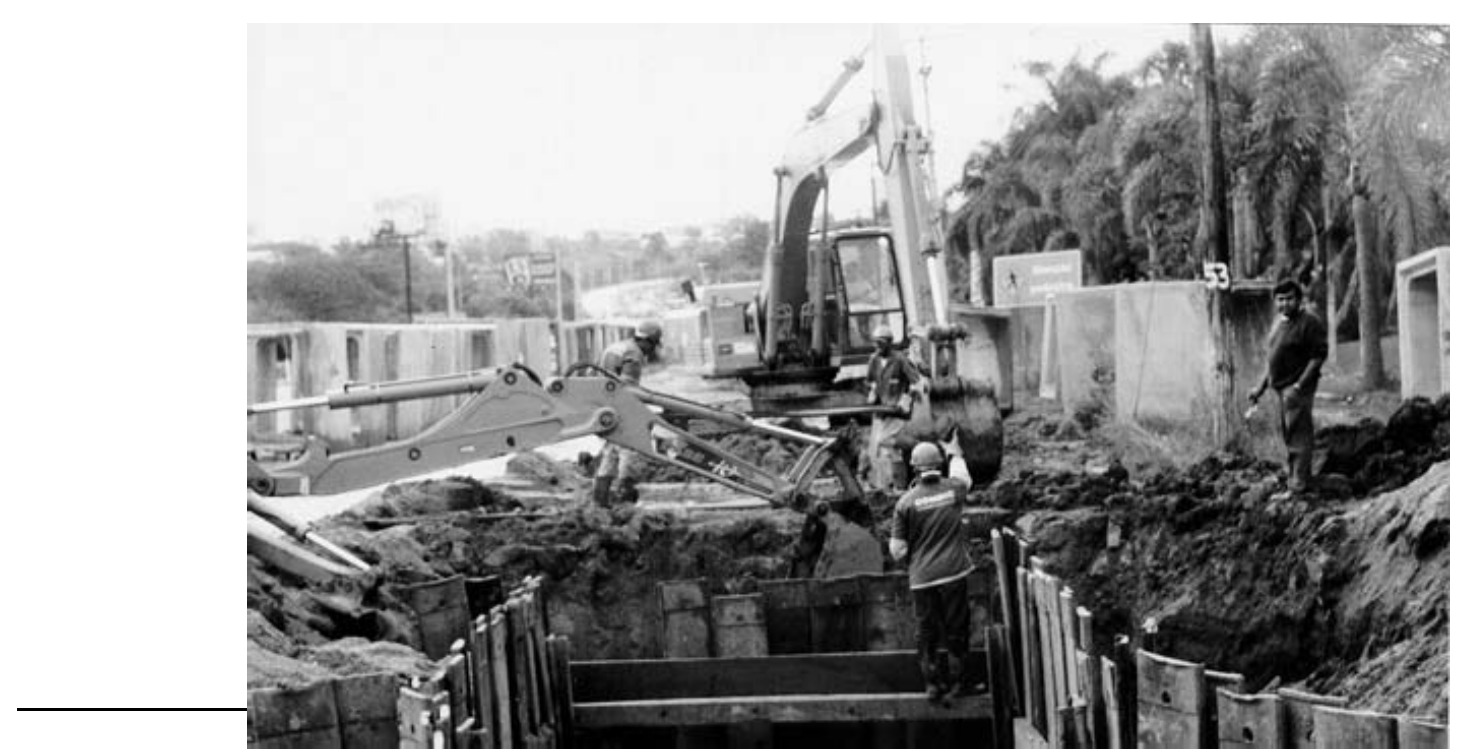

${ }^{1}$ Creio ser importante que se mencione que estes processos de transformação são visíveis em grandes metrópoles do mundo todo. Paris destaca-se como um referencial. Barão Haussmann foi o prefeito que se incumbiu de transformar a Paris medieval na Paris moderna. A reforma Passos, no Rio de Janeiro (prefeito Pereira Passos, 1902 - 1906) veio no sentido de transformar a cidade imunda em cidade higiênica, moderna e capitalista. Assim como João Baptista Ferreira de Mello cita em sua tese de doutorado, as cirurgias urbanas encontraram 'grande acolhida entre as elites modernizadoras do país, que jamais hesitaram em enfrentar qualquer apego a antigos valores, a antigas 'usanças urbanas', taxando sempre este comportamento como um indicador de conservadorismo, de atraso, de subdesenvolvimento” (MELLO,1997:195). 
A sociedade ocidental contemporânea, marcada a fundo pelo advento da revolução industrial, apresenta como característica essencial a vida urbana. A vida gira em torno da produção e do consumo, sendo que o eixo principal desloca-se do mundo rural para o mundo das cidades. Conforme Gilberto Velho recupera Hobsbawn (1975), a complexidade de nossa sociedade está fundamentalmente ligada a uma acentuada divisão social do trabalho. Neste sentido a classificação em sociedade complexa dada por Gilberto Velho (1999). Os traços fundamentais são a divisão social do trabalho e a idéia de heterogeneidade cultural que, segundo o autor, deve ser compreendida como coexistência de uma pluralidade de tradições cujas bases podem ser ocupacionais, étnicas, religiosas e etc. Kevin Linch nos diz que potencialmente a cidade é, em si mesma, um poderoso símbolo de uma sociedade complexa.
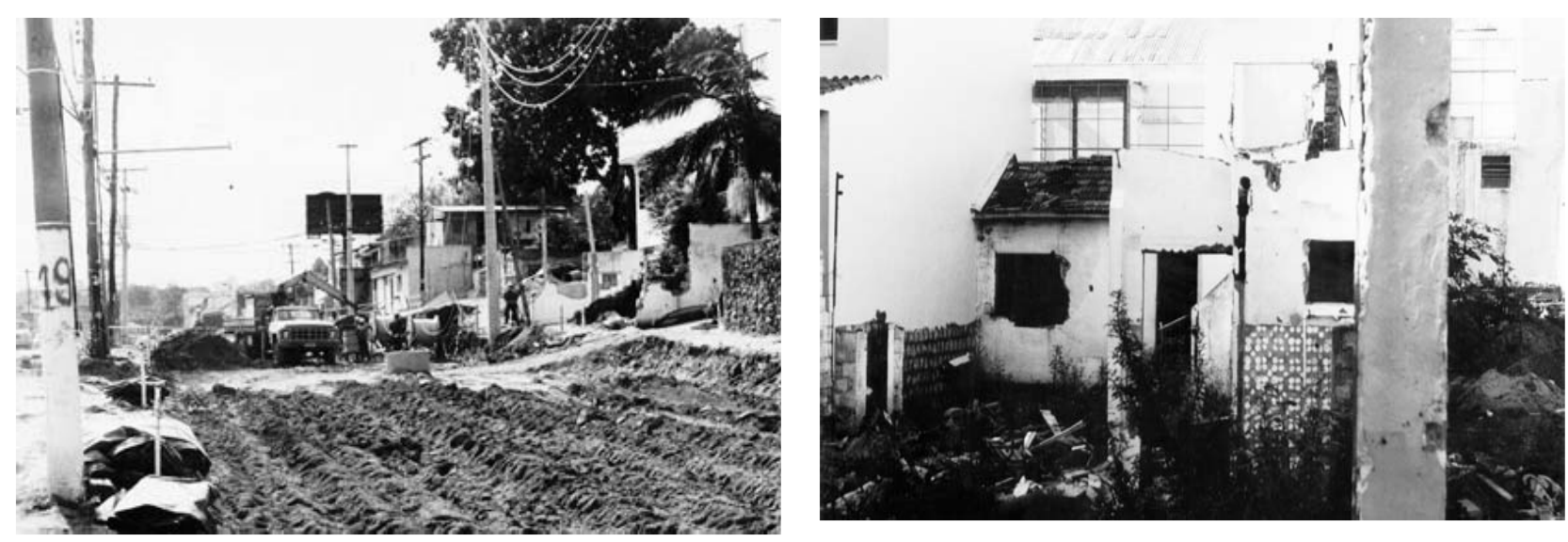

Ainda de acordo com Gilberto Velho, "uma questão interessante em antropologia é, justamente, a procura de localizar experiências significativas para criar fronteiras simbólicas" (Velho, 1999: 16). Creio que tais fronteiras podem ser compreendidas a partir de como se percebe, se ocupa e se organiza o espaço.

De acordo com Kevin Linch, “em cada instante há mais do que a vista pode ver, mais do que o ouvido pode ouvir, um cenário ou um panorama que aguarda ser explorado. Nada se experimenta em si mesmo, senão sempre em relação com seu contexto, com a sequiência de acontecimentos que levaram a isto, com a recordação de experiências anteriores" (Linch, 1974: 9). É neste sentido que se percebe a relação entre memória e espaço físico, pois o que se constrói hoje depende profundamente do que foi construído e da vivência da construção anterior. Conforme nos diz Linch, o cidadão tem largos vínculos com partes de sua cidade, e a imagem dela está fortemente embebida de recordações e 
significados, sendo que isto está estritamente vinculado com o que Bachelard chama de imaginação criadora. "O espaço percebido pela imaginação não pode ser o espaço indiferente entregue à mensuração do geômetra. É um espaço vivido. E vivido não em sua positividade, mas com todas as parcialidades da imaginação" (Bachelard,1989: 19).

\section{I. “... a história se vai..." - A memória, o tempo e os deslocamentos espaciais.}

Dentro da perspectiva da heterogeneidade cultural, especificamente tratando da base ocupacional, buscou-se uma investigação das transformações no cenário urbano a partir de um grupo urbano particular, o de antigos taxistas. Partindo-se da trajetória social e das narrativa biográficas dos entrevistados, tentando suscitar a memória, pretendemos compreender as transformações e seus efeitos na vida cotidiana. O grupo em questão foi escolhido por conta de sua atividade profissional exigir deles um vasto conhecimento dos percursos e trajetórias da cidade de Porto Alegre, além, de colocá-los em contato com diversas realidades, já que uma grande multiplicidade de tipos sociais, que explicitam a referida heterogeneidade cultural, senta naqueles bancos de taxi diariamente.

\footnotetext{
"Na minha época eu achava, eu achei sempre, que a gente fazia um serviço de utilidade pública mesmo. Porque tu levava doente, grávida tendo nenê, ganhava filho dentro do teu carro, tu ia procurar a polícia... servia para tudo. Duas mulheres tiveram filho dentro do meu carro. Elas te atacam na rua e... Bom uma vez eu vinha vindo de Petrópolis pela Protásio Alves, bem lá de cima, parei em uma senhora com uma menina disse, me leva para o pronto-socorro, o neném tá nascendo. Tá, botei a mulher no carro, nem perguntei se tinha dinheiro, e fui. Numa altura, na Vicente da Fontoura, por ali, ela diz "pára que não dá mais", e eu parei, né? Bom, aí nasceu o neném. Aí eu toquei para o prontosocorro. Isso foi sempre muito gratificante neste serviço, porque, pôxa, é um ser humano que está ali."
}

Pretendemos trabalhar com a questão dos mapas mentais, com as representações que os indivíduos possuem com relação à ambiência urbana, assim como com a noção de orientação no espaço urbano, já que estes elementos são o cerne do profundo conhecimento que os taxistas apresentam sobre a cidade. $\mathrm{O}$ que saltou aos olhos no 
decorrer das entrevistas foi uma visão da cidade, bem como uma apresentação da memória, a partir da perspectiva do deslocamento. Busca-se, desta maneira, compreender e captar o ponto de vista daqueles que utilizam a cidade e seus percursos para o deslocamento, vivendo em função dele, tirando daí seu sustento.

Uma pessoa vai ocupar o papel central neste trabalho. Edgar Luiz Bernal, taxista por mais de trinta anos, dono da fala há pouco utilizada, demonstrou-se um excelente informante, um entusiasmado narrador, mergulhando a fundo em suas recordações sobre a cidade de Porto Alegre e sua organização espacial, sobre os seus lugares de destaque, sobre as grandes obras, sobre os momentos marcantes. Eu não sou um profundo conhecedor da cidade, pois moro há apenas um ano nela, e assim, as entrevistas surgiram para mim como um meio de conhecê-la através dos olhos de alguém que a viveu por longos anos, cuja história de vida conta também a história da cidade. Sêo Edgar é um senhor de 75, de cabelos brancos, magro e baixo, muito simpático comigo. Trechos das entrevistas realizadas com ele são a base para uma viagem à Porto Alegre de outrora, para uma busca de um tempo que se foi e de uma cidade por demais diferente da que eu conheci. Buscamos a memória pois ela é como que uma luta contra a ação corrosiva do tempo. "Neste teatro do Passado que é a memória, o cenário mantém os personagens em seu papel dominante. [...] O espaço retém o tempo comprimido" (Bachelard, 1989: 28).

É na fala de Sêo Edgar que vamos buscar a percepção da organização espacial da cidade enquanto cenário, é ela que nos denuncia o elo de ligação entre a memória e o espaço físico.

\footnotetext{
"Eu sou velho, mas acho que nem tudo o que é velho é bom. A cidade tem que se expandir, tem que melhorar, mas tem que se respeitar certos valores. Não vamos chegar ali no centro e derrubar, derrubar. Veja ali onde tem o banco Guarani, que preservaram a fachada. Que coisa bonita. Era moradia da alta elite de Porto Alegre, aqueles casarões no meio dos terrenos, com muita terra dos dois lados. Não sobrou nada. Quer dizer, a história se vai..."
}

Quando Sêo Edgar nos diz que a história se vai, levando consigo coisas que foram muito marcantes em outras épocas, demonstra que na memória reside um passado que guarda coisas que não poderão ser encontradas em outro lugar. Ela mantém vivos os espaços imaginados e os espaços anteriormente vividos. A vida de Sêo Edgar mescla-se com a vida da cidade. 
Com um tom nostálgico e saudosista, ele me respondeu, quando perguntei sobre sua origem:

\begin{abstract}
"Nascido em Porto Alegre, em 1925, em plena rua 7 de Setembro, próximo da casa de cultura Mário Quintana hoje, que na época era o hotel Majestic, um dos melhores que tinha em Porto Alegre. Com a morte do meu pai, eu fui morar no bairro Navegantes, com a minha avó, e ali era o centro industrial da cidade. Então, a partir de 38 é que eu comecei a conhecer melhor a cidade, que eu comecei a sair de casa, a andar de ônibus, de ônibus não, de bonde. Aí é que a gente começou a ter uma idéia do que seja Porto Alegre. Depois em 40, teve uma grande enchente em Porto Alegre, sendo que se andou de barco em um trecho já pronto da Av. Farrapos, se andou de barco a motor. Ali na Farrapos esquina com a São Pedro deu um metro e meio de Água. Passando ali hoje a gente não imagina até onde foi a água, né?"
\end{abstract}

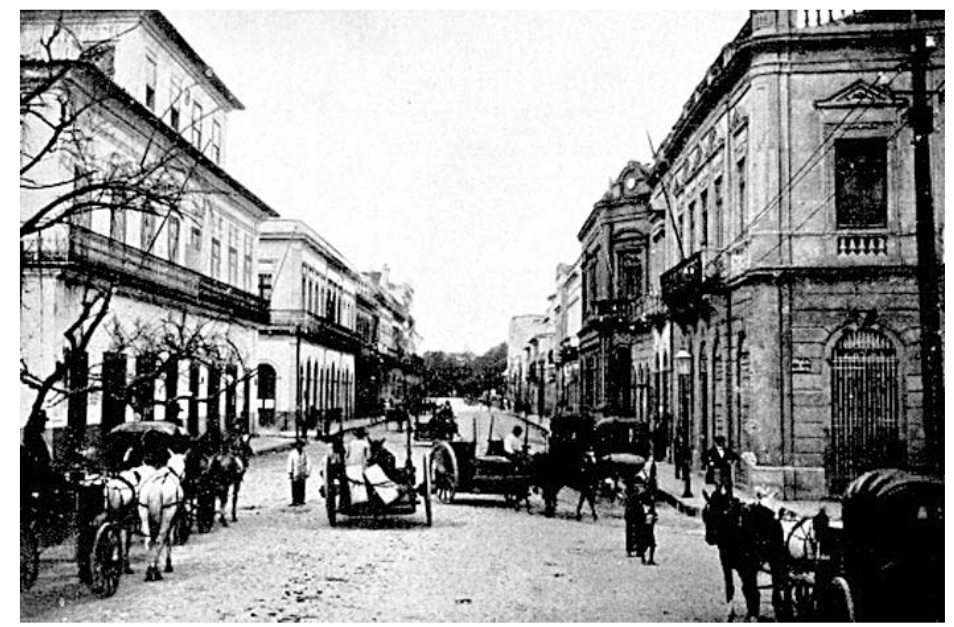

Aqui eu peço a ele que me conte novamente a história que ele estava me contando antes da gravação, cujo cerne era o momento em que ele começou a conhecer realmente a cidade de Porto Alegre.

"Eu estudava no colégio Souza Lobo, na época da comemoração dos cem anos da Revolução Farroupilha. Cada escola apresentou um tipo de trabalho. O meu grupo, eu e mais dois colegas, pela nossa habilidade manual, ficamos de dar uma idéia do que seria a zona rural do Rio Grande do Sul, apesar de eu nunca ter saído de Porto Alegre, naquela época. Só de ver e livros e fotografias. Nós fizemos uma plataforma de madeira e forramos com barro vermelho, que esta zona ali pela rua São Pedro, mais para cima da Benjamim Constant tinha uns morrinhos que tinha muito barro vermelho. Nós começamos a armar como se fosse uma campanha, assim de cerrinhos e tal; se fez uma casinha, uns postes com fios como se fosse o telégrafo, que naquela época mal e mal se conhecia luz elétrica. Inclusive aqui em Porto Alegre! Na minha casa na 7 de Setembro, era de Lampião. Depois quando eu fui morar na casa da minha avó, na Av. França também era lampião ainda. 
Então depois de pronto a gente teve que levar lá para o pavilhão e terminar de montar, porque era uma coisa grande. A gente teve que refazer muita coisa, porque tinha muita coisa caída, no transporte. Daí eu comecei a conhecer mais a cidade e a andar de bonde. O bonde Navegantes começava na Praça Parobé, vinha sempre pela Voluntários da Pátria até próximo à Igreja dos Navegantes. Depois tinha o bonde São João que vinha também, fazia o mesmo trajeto, e entrava na rua do parque, fazia um pequenos desviozinho na Av. São Paulo, entrava na Pres. Roosevelt, que na época era a rua Eduardo, depois entrava na São Pedro, atravessava a Minas Gerais que depois ficou Farrapos, e ia até a Benjamim Constant, que era o fim da linha, e fazia a junção com a linha do bonde Floresta, que saía da praça XV, Otávio Rocha, Alberto Bins, Cristóvão Colombo, Benjamim Constant, e vinha até a Igreja São João. Quando ele passava pelo bonde São João, que fazia a linha entre São Pedro e Cristóvão Colombo, eles davam um ticket que a gente chamava de baldeação e entrava no outro bonde que ia para o fim da linha e não precisava pagar passagem para o resto do trajeto. Ali é que eu comecei a conhecer Porto Alegre."

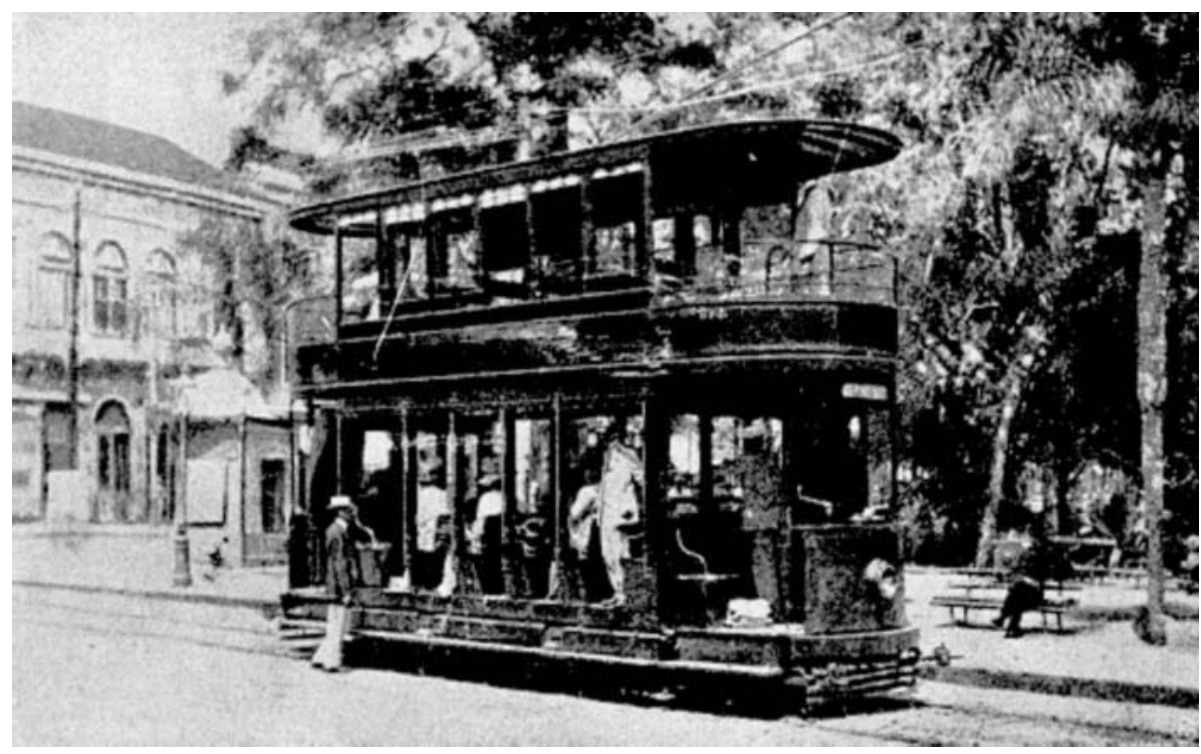


Sua narrativa começa com lembranças particulares, com uma memória íntima, com sua trajetória de vida, mesclando-se com a memória coletiva, com os fatos que marcaram a história da cidade neste século, como a enchente de 1941. O tempo aqui é marcado; ele existe objetivamente, já que datas são fornecidas. Nota-se, no trecho no qual Sêo Edgar descreve o itinerário dos bondes, que a memória se apresenta a partir dos deslocamentos espaciais, que a movimentação no espaço está profundamente presente nas lembranças que os habitantes da cidade levam consigo, sendo fundamental para o conhecimento deste mesmo. O sair de casa e andar de bonde marca a época na qual este homem passou a dominar e se orientar no território; as representações mentais do espaço exterior claramente apresentam movimento.

\section{A trajetória social e a memória coletiva.}

Neste trecho da entrevista, Sêo Edgar parte para uma narrativa mais relacionada a sua trajetória social. As memórias sobre a cidade aqui se aproximam consideravelmente da memória coletiva. Os espaços aqui tratados são os espaços amplos, de vivência coletiva.

"Depois veio a época em que eu trabalhei como ajudante de vendedor de massas. Nossa zona de atendimento era o centro. Eu comecei a andar de carro no centro de Porto Alegre e a conhecer. Depois disso eu fui para o quartel, que era no morro do Menino Deus, é até hoje, só que derrubaram o velho e fizeram um novo. Ai eu comecei a conhecer a parte desta cidade. Ali, a praia ia até a Praia de Belas... tudo aquilo ali é aterro. O mais interessante, a maior mudança foi aqui em Navegantes. Nós só tínhamos a voluntários da Pátria. Quem vem do centro pro fim da linha, do lado esquerdo da Voluntários da Pátria, ali era tudo armazéns, inclusive de atacado. Grandes armazéns, depósitos, depósitos de arroz e coisa assim. Então ali tinha as duas linhas de bonde, uma que ia e outra que vinha, e ao lado delas a linha da viação férrea, que o trem entrava em Porto Alegre e ia até onde é o viaduto hoje. Ali tinha a Estação central. Quem olha do viaduto para a rodoviária, aquilo tudo era um parque da viação férrea pra conserto, manutenção de equipamento, ramais de trem para fazer manobra, para pegar carga. Tinha um armazém da viação férrea de frente para a Rua da Conceição, que ali tinha muito parador de carroças que faziam o transporte. 
Eu conheci o centro no tempo dos carroções, geralmente puxados por três burros, e a carroça bem baixa, com duas rodas, uns enorme duns rodão, ficava quase parelho ao meio fio, para facilitar pegar carga pesada. Eram eles que faziam o transporte das cargas dos trens, e também para distribuir pela cidade. Ali onde está hoje a praça Parobé tinha uma praça com uns chafarizes, até alguns deles estão no parque Farroupilha, e tinha um bebedouro atrás do mercado onde os carroceiros levavam os cavalos para beber água."

Acho extremamente interessante a orientação espacial que Sêo Edgar demonstra. Tentando nos situar especialmente, ele se utiliza de expressões como "quem vem do centro para o fim da linha, do lado esquerdo era..." e "quem olha do viaduto para a rodoviária...”. O espaço é o mesmo, mas os construtos artificiais sobre esta configuração territorial são outros. Ele se vale do que eu conheço da cidade hoje para me orientar em suas representações mentais dos espaços do passado. Ele me envolve, assim, em sua viagem ao seu passado.

"Ainda voltando à Voluntários da Pátria, era difícil passar mês que o trem ou o bonde não pegava alguém ali. Porque o trem e o bonde ficavam muito próximos. Esse trem que corre aí hoje, o Trensurb, ele corre dentro do rio, aquilo tudo ali é aterro. Se tu pegar hoje a Voluntários da Pátria e contar uns vinte metros em direção ao rio, tu vai chegar onde era a antiga praia. Ali tinha os clubes náuticos, o GPA, o União, O Tamandaré, o Barroso, o Duque de Caxias, que cada um com uma peculiaridade, cada um com uma raça. GPA, mais alemães; União, já tinha mais uma mistura de alemães com brasileiros; O Almirante Barroso era o que a gente chama de "pêlo duro". Tu conhece esta expressão? É o que é bem aqui do Rio Grande do Sul, bem misturado, mas muito pouco, né? Depois tinha o Tamandaré, que foi o primeiro clube de regata que eu vi com negros remando. Poucos. Mais tarde teve o Marcílio Dias era só negros. Depois tinha o Vasco da Gama que era só portugueses e descendentes. Isso e na ordem de encontro. Caminhando do centro para Navegantes tu encontrava estes clubes. Aí vinha o Duque de Caxias, que era dos italianos. Era assim, mais ou menos. Muita rivalidade. O Barroso tinha muitos remadores que eram moradores das ilhas, gente que já tinha uma certa prática do que era o rio. Era o dos pêlo duro.

Depois se seguisse pela Sertório, atrás da Igreja dos Navegantes tem a rua Frederico Mendes. Ali tinha muitas indústrias. O trilho passava ali, cortava a Frederico Mendes. Ali tinha as Indústrias Render, da maneira como eu já conheci. Tinha tecelagem, a fábrica de roupas para homens, a fábrica de máquinas Renner, e do outro lado o depósito de lenhas, a fábrica de canos de concreto, o serviço de assistência médica e aí o varejo. Quando eu conheci isso, que a Renner é bem anterior a mim, tinha o refeitório. 
Questiono sobre o seu conhecimento sobre as ilhas do Guaíba, pergunto a ele se as conhece.

\begin{abstract}
"Sim. Não muito mas conheço alguma coisa. No meu tempo de mocinho, eu ia muito no Duque de Caxias. Então, como sempre fui muito magro e muito pequeno, eles me queriam para timoneiro, para fazer menos peso no barco. Então seguido a gente fazia excursão para aquelas ilhas. Saía de manhã cedo, 4 ou 5 barcos, levava um café, entrava numa ilha daquelas e alguém se encarregava de fazer o café, o resto jogava bola e coisa e tal, a gente tomava café e voltava ainda antes do meio dia. A gente ficou conhecendo um pouco. Se conheceu muitos moradores das ilhas em função do remo, muitos deles vinham remar aqui."
\end{abstract}

É interessante que Sêo Edgar sempre se lembra de trabalhos envolvidos com o deslocamento de outras pessoas. Até quando ia andar de barco era solicitado para trabalhar como timoneiro.

\title{
III. As Grandes Transformacões.
}

Eu retomo com Sêo Edgar o que já estávamos discutindo anteriormente, sobre a questão dos aterros na cidade de Porto Alegre.

\footnotetext{
"Dizem alguns, e isso eu não posso te comprovar de jeito nenhum, que esse aterro foi feito em função da enchente de 41. Isso eu li em jornais ou coisa assim, que em função do rio Guaíba ser muito largo e muito raso, sempre que venta minuano represa a água do rio. Em 41 choveu muito, tanto aqui em Porto Alegre quanto nas cabeceiras do rios, por que o Guaíba é o encontro de cinco rios. Jacuí e Taquari se juntam um pouquinho mais para cima, depois tem o Sinos e o Gravataí que é mais pra cá, e depois tem o Caí. Então começou a descer a água das cabeceiras dos rios justamente na época que estava tendo o minuano, e represou o Guaíba e ela veio subindo e $v$ eio até, passou ou pouquinho da José Montauri, ali na Borges de Medeiros, a água. Aí diz que em função disso, uns engenheiros estudaram $e$ disseram que se a gente encolher o Guaíba e aprofundarmos, vai dar melhor vazão. Eu até acho que tem um fundo de verdade, porque melhorou muito a vazão do rio."
} 
"Quando começou as obras do aterro? Foi depois de 41. Em 54 já estavam fazendo a ponte, então foi aí por 47, 48. E a travessia para ir para o sul do estado, tu tinha que atravessar toda a cidade, ir até a Vila Assunção e atravessar o rio de Barca. Logo que terminou a guerra, vieram umas barcaças feitas para desembarque, da Europa. Cabia acho que uns quarenta automóveis dentre. Nessa época eu tinha caminhão e para agente passar lá para o lado de Guaíba para ir até Rio Pardo Buscar cal, a gente tinha que entrar na fila. Tinha ocasião da gente entrar na fila às onze horas da noite e atravessar no outro dia as nove horas da manhã. Tudo com balsa. Aí construíram a ponte, que foi uma luta para sair essa ponte. Hoje quem passa ali pela ponte nem se dá conta. É barbada. Mas a falta de uma ponte no Guaíba atrasou muito o Rio Grande do Sul. O pessoal hoje fala que a metade sul é pobre. Mas para ir para lá só tinha o trem. Para ir para Bagé, por exemplo tu pegava um trem em Porto Alegre, ia em direção a Canoas, entrava à esquerda, passava por Triunfo, Rio Pardo, Cachoeira, Santa Maria. Aí fazia a baldeação. O trem que ficava em Santa Maria subia a serra e ia para Tupã, Júlio de Castilhos e Cruz Alta. Se tu queria ir para Bagé, pegava outro trem. Se tu olhar no mapa, a distância que percorreu foi três vezes mais do que precisava. Isso Atrasou, porque que é que vai construir indústria lá se não dá pra chegar em Porto Alegre. A estação ferroviária era muito bonitona. Ficava onde é hoje Voluntários da Pátria, Conceição e o viaduto. Depois os trilhos, que passavam mais ou menos onde é a rodoviária, pegavam a Mauá e iam até os fundos do mercado. Tinha uma estaçãozinha ali. Era um ônibus que andava nos trilhos. Chamava carro motor. Ia nele até São Leopoldo, Novo Hamburgo, Taquara, mas a estação dele, para embarque e desembarque era na Borges com a Mauá. A garagem deles era, sabe onde é a ponte de pedra? Do outro lado do riacho. Ele subia pela Mauá, fazia a volta na Usina do Gasômetro, passava em frente à cadeia, defronte os depósitos de gás para ir lá pelo outro lado. Não tinha como passa pelo riacho, ali no centro, porque a foz do riacho é mais ou menos na frente da onde hoje está a ACM. Ele vinha seco porque ele vinha por trás da foz dele. Esse riacho deu origem ao arroio Ipiranga. Ele vem lá da divisa de Viamão, lá na Lomba do Sabão, No parque Saint Hilaire, aí o riacho vinha pelo Partenon, e ficava entre o Partenon e Petrópolis. Era muito tortuoso, ali onde está o a PUC e o hospital da PUC era tudo banhado. Quando mocinho, a gente ia fazer uns passeios ali no Champagná, e a gente passava o dia jogando futebol e ia tomar banho mais ou menos onde está a PUC, e o rio passava nos fundos da onde hoje está o hospital de clínicas. Ali tinha a ilhota, que era onde está hoje a RBS, um pouquinho mais em direção ao centro, à Getúlio Vargas. Era uma vila onde nasceu e se criou Lupiscínio Rodrigues. Ali ele vinha, desviava um pouquinho para a direita e entrava na rua João Alfredo. Ali na parte da esquerda só tinha uns vinte metros de casa e já começava o riacho. Como hoje, era tudo lixo ali.

Ele avançava um pouco, passava a Borges e chegava na foz. Aí então resolveram canalizar o arroio. Porque se tu estava em Petrópolis e quisesse ir ao Partenon tu tinha que ir lá perto da onde está o Pronto Socorro, pegava a Venâncio Aires para depois pegar a Santana. Nessa época eu tinha caminhão, trabalhava na Renner carregando argamassa. Era uma luta quando tinha que ir na Glória, Teresópolis, Partenon, porque tu tinha que rodar quase a cidade inteira para atravessar o rio."

O riacho mencionado por Sêo Edgar hoje é canalizado, e em suas margens corre a Avenida Ipiranga, uma das mais movimentadas da cidade. Novamente aqui creio ser 


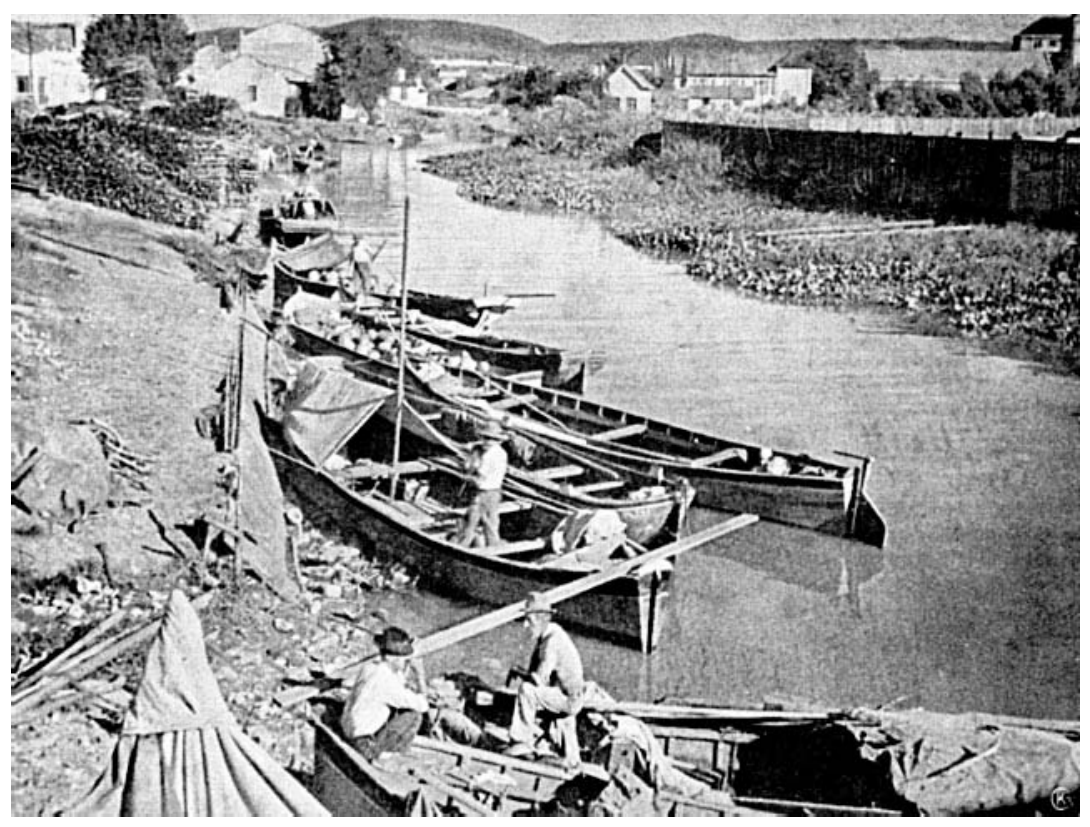

importante salientar a surpreendente orientação espacial que o entrevistado demonstra quando trata dos percursos do trem em direção ao interior do Estado. Há, claramente definidos, pontos que orientam o meu pensamento sobre os espaços dos quais ele trata.

Em um momento em que eu ainda não estava gravando, conversávamos sobre a construção da Avenida Farrapos, e Sêo Edgar contou-me que o prefeito Loureiro fez um levantamento de preços dos terrenos onde passaria a nova avenida sem declarar o porquê, desvalorizando-os, cotando-os em um preço inferior ao que seria procedente, e as pessoas assinaram.

"O Loureiro, um ano depois do levantamento dos preços, resolveu iniciar as obras. Estas obras foram muito rápidas. Inicialmente a Farrapos era assim: uma pista larga que dava para dois carros passaram, de paralelepípedo, aí um canteiro, aí uma faixa de concreto que dava para dois carros numa mão e dois carros noutra, e aí mais uma faixa de paralelepípedo. A Farrapos não tinha Cruzamento. Quando chegava uns dez metros antes da esquina, o canteiro interrompia, e depois da esquina recomeçava. Quem descia da Ramiro Barcelos em direção à Voluntários da Pátria, não podia atravessar direto. Tu saía para a direita até chegar a abertura, passava para o outro lado, e entrava na Ramiro de novo. Não tinha cruzamento. Só tinha cruzamento na São Pedro, a do Bonde São João. Nesses canteiros todos era plantado álamo, aí vem um prefeito e outro e acaba mudando tudo. Terminou fazendo um corredor de ônibus como é hoje. Com a abertura da Farrapos melhorou uma barbaridade o 
trânsito dentro da cidade. Hoje se tu quer pegar a BR116, tu pega a Farrapos e vai reto, vai-te embora. Tu quer ir para Gravataí, Osório, para as praias, pega a Farrapos e entra na Sertório, depois na Assis Brasil e vai embora. Tudo graças à Farrapos. Depois disso nenhuma avenida, a não ser a Ipiranga, foi feita para melhorar o escoamento do trânsito."

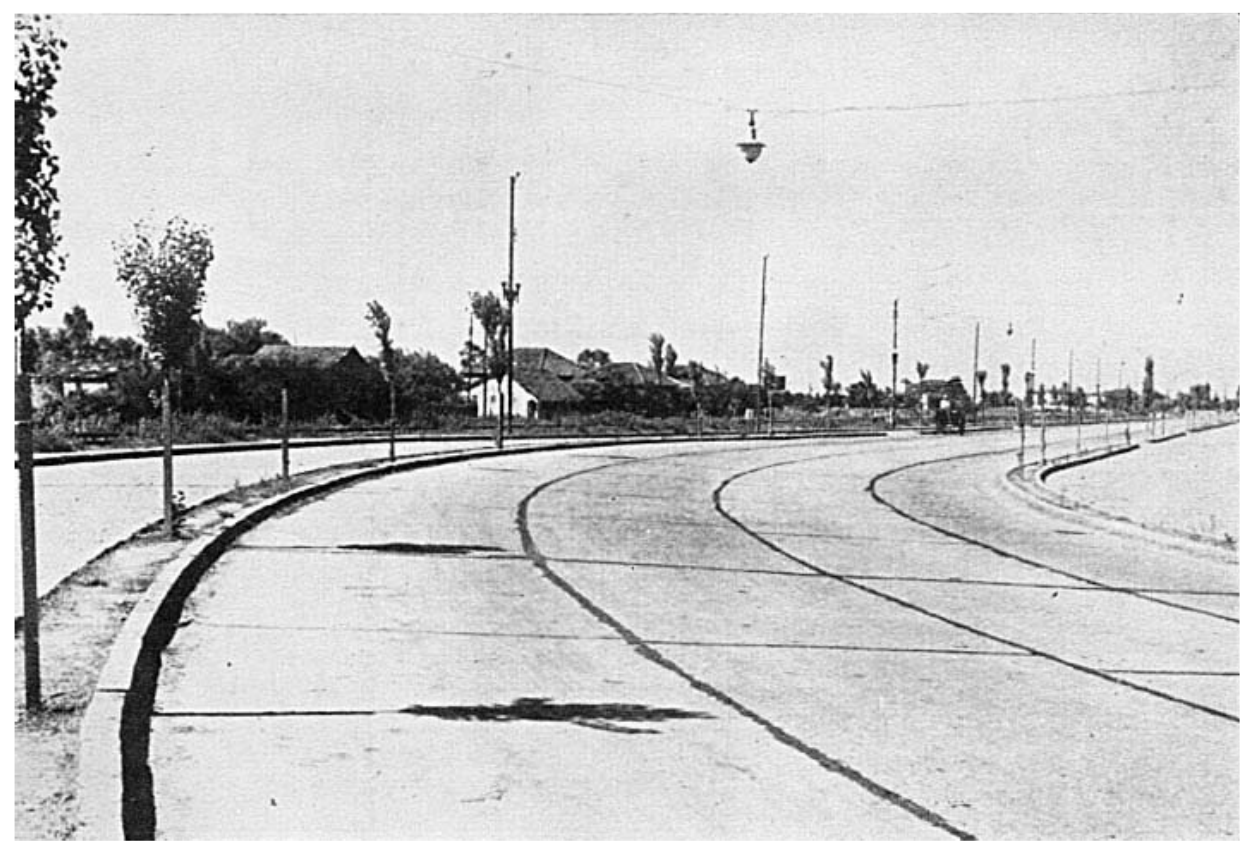

Eu questiono, então, sobre a construção da terceira perimetral, mencionado que o objetivo é, também, uma melhoria no trânsito, que é um outro anel viário que liga bairro com bairro, desviando o trânsito do cetro da cidade.

"Sem dúvida é muito necessário, afinal Porto Alegre não pode ficar parada no tempo, né? Essas transformações afetam inclusive a população. A gente que sempre morou em Porto Alegre custa a se adaptar a essas modificações. Como eu morava na 7 de Setembro, vinha tranqüilamente até a Caldas Júnior pegar o bonde e vinha até aqui a entrada da vila do IAPI, e vinha tranqüilo. O bonde é um dos transportes mais seguros, eu acho que nós não vamos ter um transporte seguro como o bonde." 
Também aqui a memória é uma memória coletiva. As grandes obras estavam lá para serem vistas por todos. O aterro, a construção da ponte, a construção da Farrapos, a canalização do Arroio, a construção da Avenida Ipiranga.

\section{Espacos vividos, tempos fantásticos.}

Neste momento eu ponho em assunto a questão da destruição de um patrimônio em função das transformações na estrutura da cidade. Coloco que aqui não se preocupa muito com isso. Retomo o que já foi citado, de Abreu, em nota de rodapé, sobre a questão das elites transformadoras acusarem este sentimento como conservadorismo.

"Absolutamente não! Começa a ficar meio velho o pessoal já derruba. Quando falaram que iam demolir aquele prédio ali na Esquina da Conceição, ali no viaduto, por causa de estar muito perto do viaduto, estar muito feio, me deu uma pena! Pára um pouquinho e olha, que coisa linda aquele prédio! Outro prédio que me encanta é aquele onde era a confeitaria Rocco

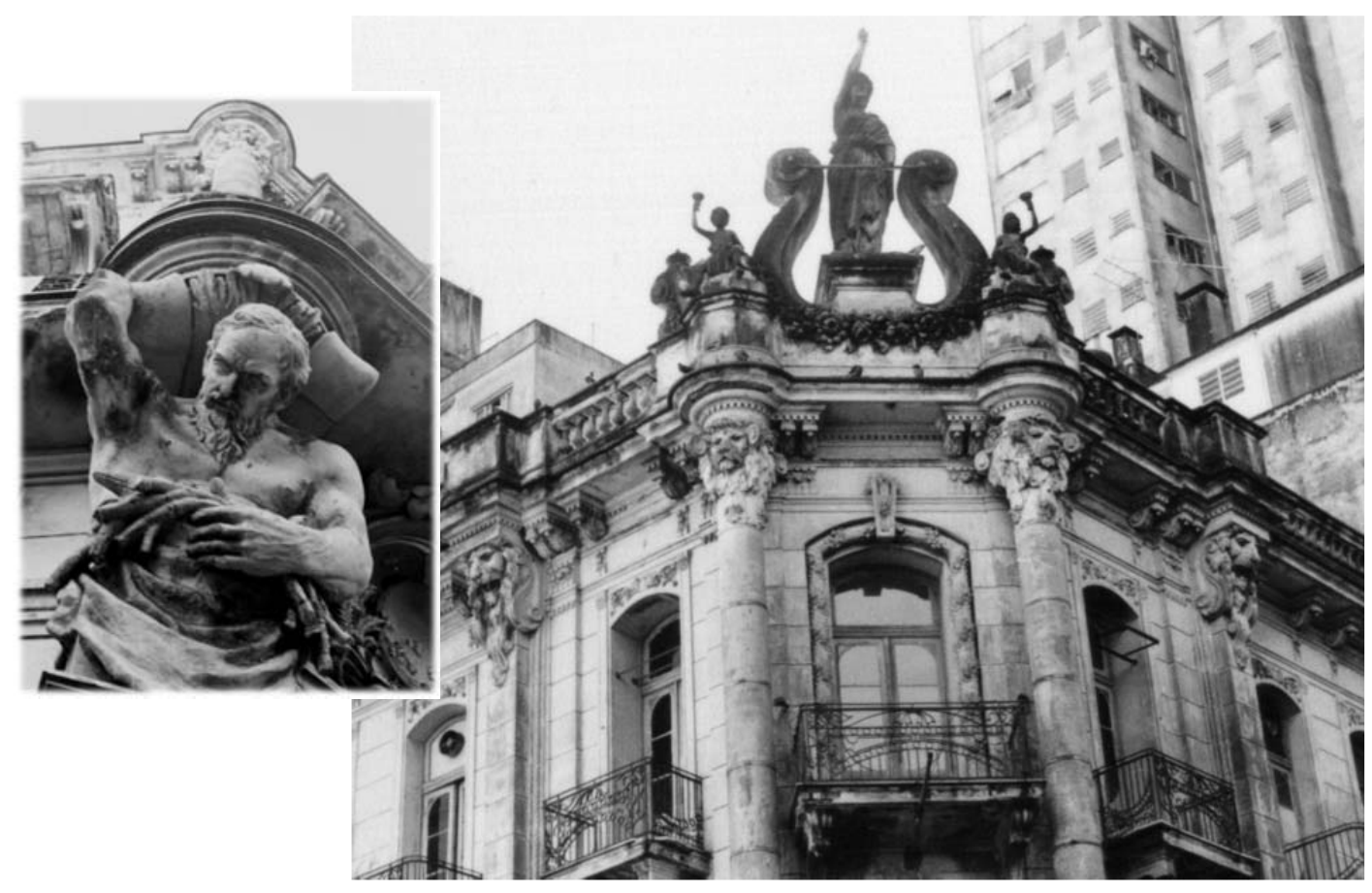


. Eu lembro quando menino que aquilo era um ponto de encontro da elite. As senhoras e os senhores iam lá de tarde, tomar seu chazinho, comer doce... e os doces da confeitaria Rocco eram famosos em todo o Rio Grande do Sul. E agora está lá atirado aquele prédio, nem sei se não vão acabar demolindo aquilo, o que é uma lástima. Outro prédio que também sempre me encantou é esse do Banco Comercial Industrial do Sul. Ë outro prédio que é uma relíquia que também deveria ser preservada, que nem preservaram o prédio dos correios e telégrafo e o MARGS, que ali era da antiga receita, uma outra jóia."

Creio que esta tensão da destruição de um patrimônio de extrema importância na vida de Sêo Edgar remete-o a memórias que não mais apresentam um tempo sincrônico. Os espaços vividos por ele estão envoltos, agora, por um tempo fantástico, intransitivo. Eu menciono, após sua fala, o Hotel Majestic.

\begin{abstract}
"Do pátio da minha casa a gente via os quartos e tal. Então de vez em quando eu fugia, entrava naquela ruazinha que depois chamaram de Rua dos Cataventos para mexer com aquelas pessoas que estavam nas passarelas. $\mathrm{Na}$ frente ali da Casa de Cultura tem a 7 de Setembro, Siqueira de Campos e terminava. Dali até o cais era um terreno baldio, tinha uns ramais da linha férrea, alguns vagões que não encostavam bem na porta do armazém para carregar ficavam ali. Então quando aquele carregava vinha a locomotiva, tirava ele dali e entrava o outro. Na Revolução de 30 eu lembro que eu saí da minha casa e fui até a esquina da João Manoel, e olhava para o porto e estava a tropa estacionada ali esperando para embarcar num navio. Foi onde eu ouvi cantar pela primeira vez o hino à João Pessoa, e eu fiquei com aquilo... até hoje eu me lembro do refrão. Aquilo era, assim, um matinho, um capim meio alto, pardo. Depois começaram a vir do centro em direção à usina do Gasômetro e aí que começaram a calçar e melhorar a Avenida Mauá. Aquele trecho ali foi em 35 ou 36, não antes disso."
\end{abstract}

Este último parágrafo explicita bem a relação do homem com o espaço, já que

os lugares trazem recordações de hábitos particulares antigos, de momentos relevantes para a sua vida. Creio ser importante retomarmos aqui o que já foi citado com relação aos espaços da memória enquanto espaços vividos com todas as parcialidades da imaginação.

\footnotetext{
"Uma coisa que era muito bonito em Porto Alegre era o passeio, o footing na Rua da Praia. Nos fins da tarde, nos Sábados, nos domingos, as moças e os rapazes ficavam para cima e para baixo ali na Andradas. Muitos amores foram bolados ali... Tinha o café Central, que hoje tem o Banco do Estado de São Paulo, ali no Largo do Medeiros. Ali na frente tinha um café, o café Central, que era também um ponto de encontro dos intelectuais, jornalistas..."
} 
"Ali na Caldas Júnior com Andradas, tinha o Grande hotel, onde se hospedavam as grandes figuras do Estado e do Brasil quando vinham a Porto Alegre. Eu lembro que tinha uma entrada de serviços e tinha chuveiros, e no inverno o hotel cobrava uma taxinha para a gente tomar banho quente. Muita gente tomava banho ali. Ou ia ou esquentava água no fogão e tomava banho numa bacia. Ali ainda tinha WC, mas na casa da minha avó era o famoso cubo. Era um barril de madeira cônico, e tinha uma tampa e um arco de ferro que prendia. Então as pessoas faziam as necessidades ali e uma vez por semana eles vinham trocar este cubo. Eram uns carroções grandes de quatro rodas, com quatro mulas, que tinha uma caixa grande, e é como o caminhão de gás hoje, eles levavam o cheio e deixavam o vazio. Mas muitas casas era porta e janela e eles passavam com aquilo dentro de casa. Então de vez em quando no almoço... e depois daquilo cheio, eles iam despejar. Ali depois do estádio do Inter tem uma lombinha que eu sempre conheci como o asseio. Ali tinha uma usininha e era o despejo. Então tinham umas calhas que levavam até dentro do rio. Eles despejavam e jogavam água e levava rio abaixo in natura. Os caras eram os cabungueiros. Todo o centro era assim. Eu me lembro de ter visto aquelas carrocinhas ali pela Demétrio Ribeiro, a Pinheiro Machado. Os condutores eram três ou quatro homens, com aquelas calças grossas de tanto roçar com aquilo. Nisso Porto Alegre melhorou muito."

Os espaços que antes eram os espaços da memória e da vivência coletiva agora são os espaços de sua vivência íntima. Eles nos trazem idéias do que seria a Porto Alegre de outrora, eles nos permitem imaginá-la mais do que outro momento de sua fala. Aqui é que se reconstrói a Porto Alegre vivida...

\section{Conclusão.}

A Porto alegre antiga vivida por Sêo Edgar está aí: fatos marcantes como a enchente de 1940 são relembrados; os meios de transporte que marcaram época, como o bonde, os carroções, o trem, estão presentes; a vida quase sem luz elétrica era a realidade; os clubes náuticos, por exemplo, nos mostram a cidade muito ligada com o rio; os principais lugares, os prédios mais famosos, as áreas mais movimentadas, os pontos de encontro, tudo isto vem à tona. As condições higiênicas da cidade antiga podem ser imaginadas quando ele nos conta sobre os cubos e a usininha na lomba do Asseio. As grandes transformações que marcaram época são relembradas: o aterro, a construção da Avenida Farrapos, a construção da ponte

para a travessia do Guaíba, a canalização do arroio. A destruição de grande parte do patrimônio da cidade antiga para construção de novas intervenções no espaço, em outras palavras a destruição criativa, nos transparece uma cidade que desloca-se no tempo, que se 
modifica, que se reestrutura. Conforme já foi dito, a memória pode nos remeter aos espaço de um tempo passado. Sêo Edgar, ao fim de uma entrevista, quando nos despedíamos, me disse que a entrevista tinha sido muito gratificante para ele pois, pelo menos, quando ele morresse, sabia que sua memória iria estar em algum lugar. Para mim, a gratificação pelo trabalho se tornou ainda maior.

\section{Referencias}

BACHELARD, Gaston. A Poética do Espaço; São Paulo: Martins Fontes, 1993. LINCH, Kevin. La Imagen de la Ciudad; Buenos Aires: Ediciones Infinito, 1974.

MELLO, Jõao Baptista F. Dos Espaços da Escuridão aos Lugares de Extrema Luminosidade - O Universo da Estrela Marlene como Palco e Documento para a Construção de Conceito Geográficos; Rio de Janeiro: UFRJ, 1997.

OLIVEIRA, Clóvis S. Porto Alegre e sua Formação; Porto Alegre: Metrópoles, 1993.

VELHO, Gilberto. Individualismo e Cultura; Rio de Janeiro: Jorge Zahar ed, 1999. 